\title{
A DISCRETE CHOICE APPROACH TO DEFINE INDIVIDUAL PARKING CHOICE BEHAVIOUR FOR THE PARKAGENT MODEL
}

\author{
ANNUM KHALIQ ${ }^{1}$, PETER VAN DER WAERDEN ${ }^{2}$ \\ \& DAVY JANSSENS ${ }^{1}$ \\ ${ }^{1}$ Transportation Research Institute (IMOB), Hasselt University, Diepenbeek, Belgium \\ ${ }^{2}$ Faculty of the Built Environment, Eindhoven University of Technology Eindhoven, The Netherlands
}

\begin{abstract}
PARKAGENT is an agent based model for simulating parking search in the city. In PARKAGENT, the agents choose a parking spot based on the expected number of free parking spaces, distance to destination and length of parking space. For a true representation of underlying parking choice behaviour of agents in PARKAGENT model, a behavioural model is required. Behavioural models are considered as the core of agent based simulations, therefore a behavioural model capable to exhibit parking choice process in PARKAGENT has been proposed in this paper. This model explains that parking choice is based on the principles of utility maximization. Several research studies have used discrete choice models to describe parking choice phenomena. Discrete choice models determine the utility associated with choice of services and products. It is assumed that individual make decisions rationally, it is very difficult to measure the actual utility associated with a parking space. For a realistic calculation of the utility, factors affecting parking choice such as (parking cost, distance to destination, etc.) are required. In this research, the choice of on-street parking is considered keeping in view the factors associated with the street situation (e.g. occupancy, security). The decision of an agent to choose a street for parking is based on the factors associated to street. The necessary data is collected through stated choice questionnaire. The collected data is analysed using a discrete choice model (multinomial logit model). The results indicate show that the identified attributes of streets significantly affect the parking choice behaviour of agents.
\end{abstract}

Keywords: discrete choice model, agent based parking simulation model PARKAGENT, factors affecting on-street parking choice.

\section{INTRODUCTION}

The aim of urban mobility plans is to attain sustainable urban transport system that ensures accessibility and quality of urban environment. These goals can only be accomplished with the help of certain forecasting tools. These tools provide the assessment of the future situation and support in making well informed decisions. Traffic induced due to parking search has significantly grabbed the attention of policy makers. It is crucial to model parking behaviour of motorists, in order to identify the effect of change in parking behaviour on the overall travel behaviour of drivers. Understanding and modelling parking choice behaviour is essential for urban planning and decision making. It is necessary to find, measure and model all the relevant factors influencing individual parking choice behaviour and decision-making processes.

Parking choice process involves decision making. An efficient parking model should represent drivers parking choice more accurately, therefore behavioural models are considered as the cornerstones of agent based simulations. The major challenge in developing an agent based parking simulation model is the realistic nature of the parking choice behaviour model. The concept of discrete choice modelling can be used to interpret parking choice behaviour of car drivers. According to this approach, an individual evaluates different characteristics (attributes) associated with the available options (alternatives) while selecting 
a parking place. These attributes can help to define parking choice behaviour of individuals. The researcher need to identify parking choice related attributes. All these attributes and alternatives if combined in a set, can depict a realistic decision-making process (Train [1]). Although, it is difficult to represent this cognitive decision making in a mathematical form therefore, the stochasticity of decisions is modelled using probability (Train [1]).

Three agent based parking models have been mentioned in literature. These include PARKAGENT (Benenson et al. [2]), SUSTAPARK (Dieussaert et al. [3]) and the MATsim model (Waraich and Axhausen [4]). In all these models, agent's decision for selecting a parking place is calculated using different factors. For PARKAGENT model, factors such as distance to destination and length of parking place are considered by the agents to select a parking spot (Benenson et al. [2]). Whereas, in SUSTAPARK the utility of parking space is calculated with respect to parking cost, egress time, access time and search time. In MATsim model, parking choice behaviour is based on search time, walking time and parking cost (Waraich and Axhausen [4]). The objective of this paper is to propose a behavioural model capable to exhibit parking choice process in PARKAGENT based on the principles of utility maximization (discrete choice approach). It is proposed that the agent should select a street with the higher utility to park its car. To calculate this utility preference, the factors affecting parking choice are identified on the level of streets (proposing that drivers' decision to park on a street is based on the characteristics of the individual street segments rather than a parking spot). These factors can depict the parking situation in the street which affects drivers' choice for selecting on-street parking.

The paper is organized in the following sections. Section 2 discusses representation of cars drivers' parking behaviour in PARKAGENT. Section 3 explains the proposed behavioural model of parking choice in PARKAGENT. Factors affecting parking choice are listed in section 4 . Conclusions are explained in section 5.

\section{CAR DRIVERS' PARKING BEHAVIOUR IN PARKAGENT}

PARKAGENT is an agent-based spatially explicit parking simulation model. As an agent based model it has three basic elements (environment, agents and rules). The environment in PARKAGENT consists of several geographical layers (road network, parking places and buildings) of the city under investigation. The parking range and duration are defined at the beginning of the simulation. The model has a simulation time of one hour

The behaviour of the agent in the system is represented by a set of the rules. These rules are given below (Benenson et al. [2]):

1. Driving towards the destination, estimating the parking supply.

2. Searching for parking.

3. After passing the destination

4. Staying at the found parking place.

5. Leaving the parking place and driving out of the system.

According to these rules the driver enters the system by arriving randomly at a street segment within the defined distance $(400 \mathrm{~m})$ from the destination. As the driver arrives close to parking range $(250 \mathrm{~m})$, he actually starts searching for parking. At this distance, the model driver continuously re-estimates the fraction of unoccupied parking places $\left(\mathrm{P}_{\text {unoc }}\right)$.

The agents' decision to park is based on expected free parking spaces. The expected free parking spaces $\left(\mathrm{F}_{\text {exp }}\right)$ is calculated by unoccupied parking places $\left(\mathrm{P}_{\mathrm{unoc}}\right)$, distance to destination and length of parking space. The distance to destination varies at each instance of simulation, as the agent moves in the system. The values of this distance to destination 


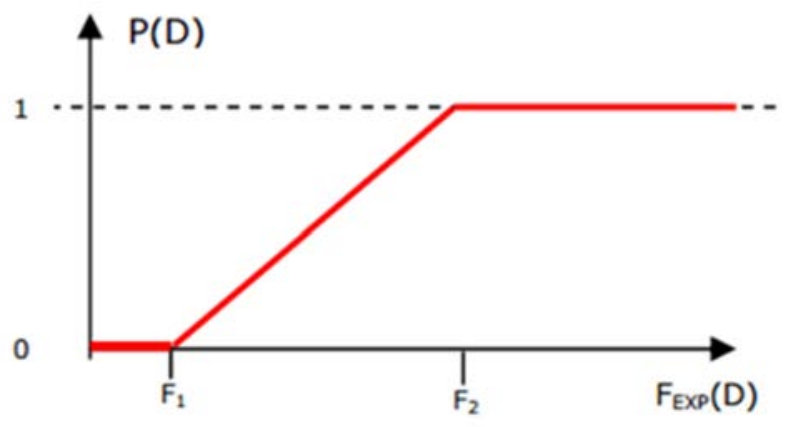

Figure 1: The probability to continue driving depends on the expected number of unoccupied parking places between the current location and the destination. (Source: Benenson et al. [2]).

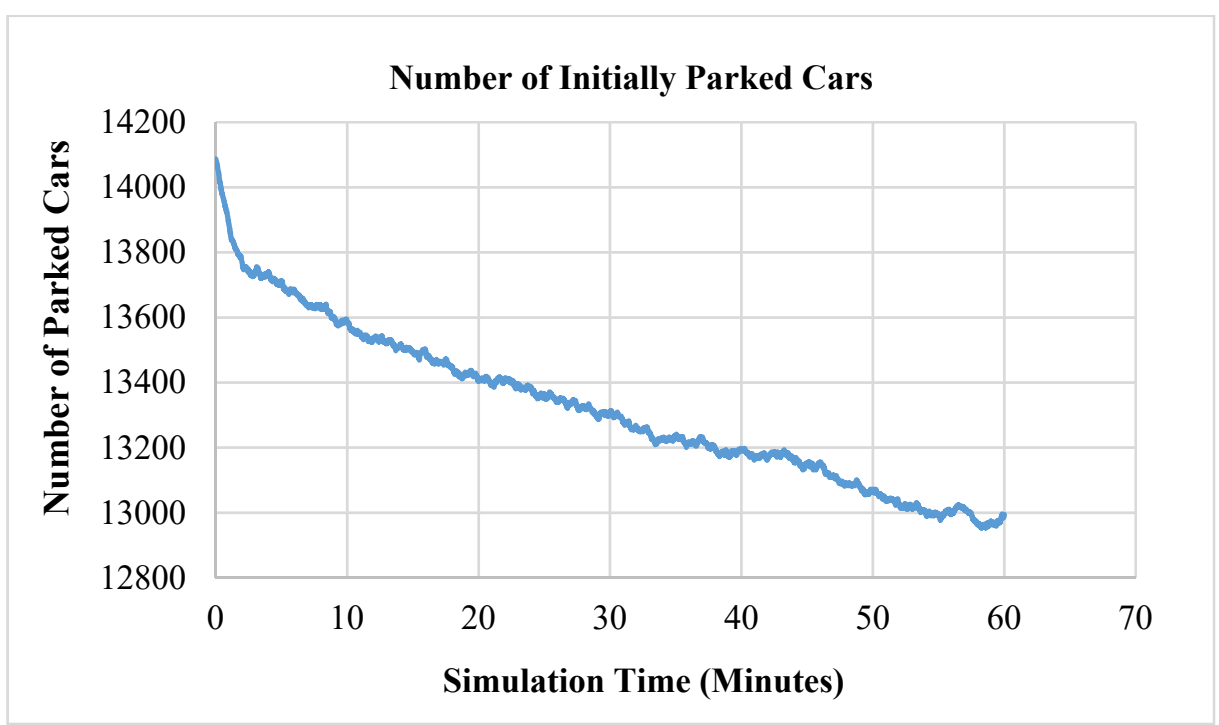

Figure 2: Number of initially parked cars is reducing as the rules of the model state that after being parked the agent/driver leaves the system.

ranges from $100 \mathrm{~m}$ to $400 \mathrm{~m}$ while the length of the parking space is fixed at $4 \mathrm{~m}$. If the value of expected number of parking places $\left(\mathrm{F}_{\exp }\right)$ is 1 or lower, the car driver parks at the first vacant parking place.

For PARKAGENT model, the chance that the car driver keeps on driving is defined by the probability $P(D)$ represented in (Fig. 1). The values of $F_{1}$ and $F_{2}$ are fixed in the current application of the model.

The output of PARKAGENT model consists of number of initially parked cars and the number of cars moving in the system from the start till the end of simulation, shown in (Fig. 2) and (Fig. 3). 


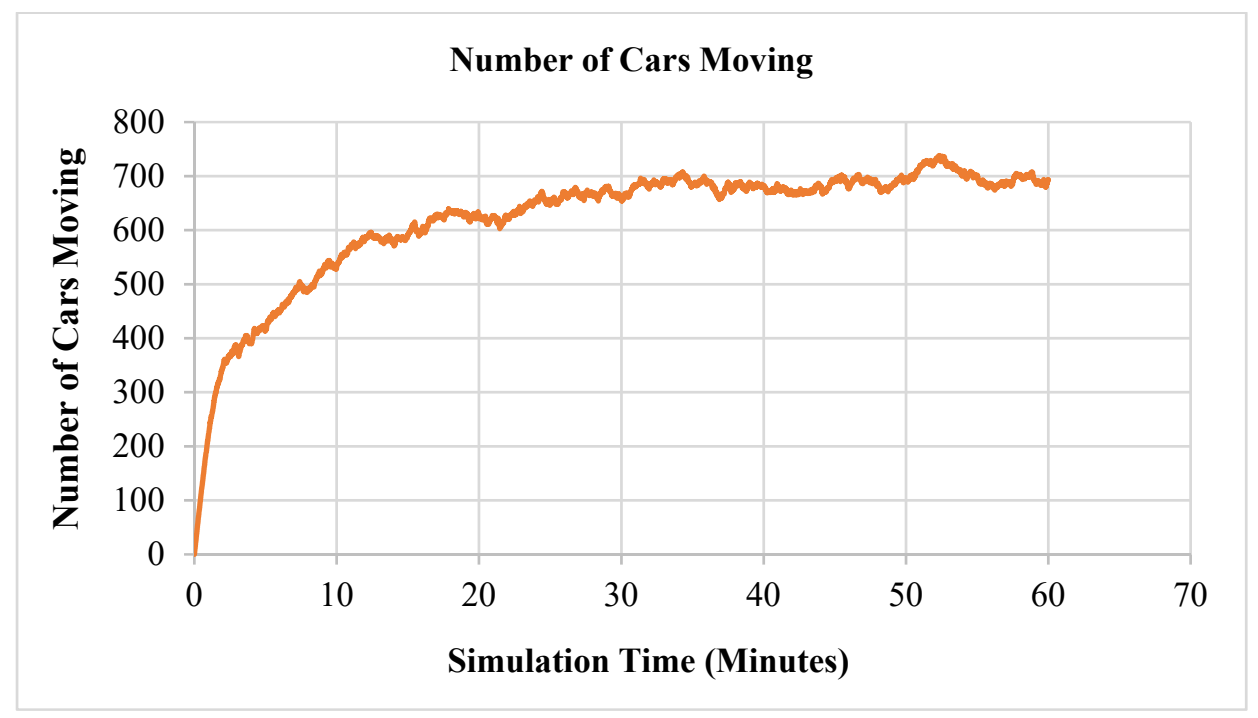

Figure 3: Number of cars moving in the system increases as the simulation time increases.

It should be noticed that the system has a fixed number of initially parked cars at the start of simulation which continuously vanish from the system while the number of cars moving in the system keeps on increasing till the end of simulation. The simulation results shown above correspond to the rules of the model that depict agent's behaviour in the system. All these rules succeed to represent parking search mathematically but are deficient to exhibit the actual parking choice behaviour of agents, as it is assumed that individuals make choices rationally. To represent a realistic parking choice behaviour of car drivers, use of discrete choice approach is indispensable. According to [1] 'Discrete choice models can be used to understand and represent the behavioural process that leads to individual's decisions'. Environmental factors and personal needs also affect individual decisions.

\section{EXTENSION OF AGENTS' ON-STREET PARKING CHOICE BEHAVIOUR IN PARKAGENT}

The concept of discrete choice modelling can be used to interpret parking choice of car drivers. In PARKAGENT, at each model iteration the agent tries to evaluate which parking spot he/she should choose for parking. The decision of an agent to park at a parking place should consider the factors associated with trip (e.g. purpose, duration, frequency, etc.), parking (type, location, etc.) and personal characteristics (e.g. age, gender, income,. etc.). Ideally, the discrete choice approach should be employed for representation of parking choice in the model. Some researchers such as (Ben-Akiva et al. [5]) have used discrete choice methods to develop sophisticated route choice models. They presented a route choice model for large-scale urban networks. The selection of route in this model was based on the alternatives presented in the choice sets. Similarly, (Vitetta [6]) specified and compared random utility model (RUM) and the quantum utility model (QUM) for simulating transport demand to represent route choice. Although, several research studies have used discrete choice models for representing parking choice behaviour of motorists for both on-street and off-street parking type. The major focus of the studies found in the literature was to identify the factors related to parking place but none of these research studies has focused to identify 


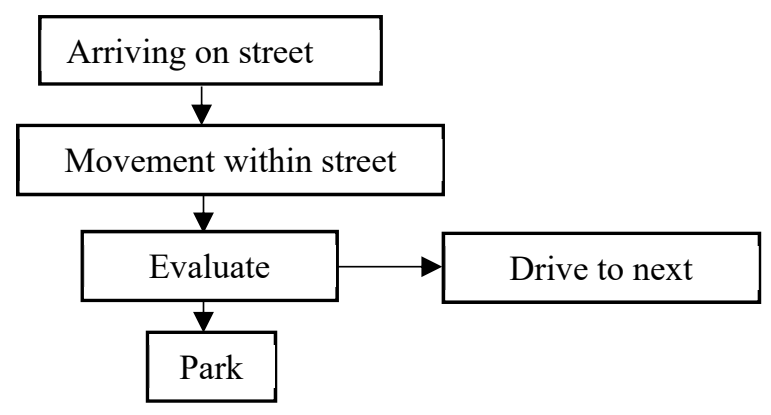

Figure 4: Concept of street parking choice process.

factors of the street itself. To elaborate more, think of an agent driving towards the destination. During the journey, the driver selects the route that takes it closest to the destination, this route choice is based on shortest path1 algorithm (Benenson et al. [2]). While driving, it passes through a number of streets. While reaching closer to the destination the agent starts to actually think whether it should drive ahead or to stay within the same street. This means there is certain utility associated to each street. There are certain street related attributes (characteristics) that the agent considers while searching for parking. For example, if a driver is driving in a crowded street he will decide to go to the next street on certain factors that he considers for leaving the current street and going further. Accordingly, there are some factors that the driver considers for deciding if he is going to drive further or park in the street. At every instance of driving he evaluates either to park in the current street or go ahead. This concept of on-street parking choice has been shown in the (Fig. 4).

Keeping in view the discrete choice approach and on-street parking process explained above. The decision of an individual to park on-street depends on the utility $\left(U_{i}\right)$ of an individual $i$. In case of on-street parking street level attributes play an important role. Assume for any given individual, there will exist an amount of utility for each street he passes by, while searching for parking. This utility is calculated from the (preference) weights the individual decision maker places upon the attribute levels intrinsic for that street (observed or unobserved). Consider that the decision of an individual to park on-street is based on certain attributes relative to that individual and on-street parking. The value of the utility $\left(U_{i}\right)$ can be calculated based on the personal attributes of the individual $i$ and the street characteristics available to that individual $i$. The relationship between personal attributes and street attributes can be represented by eqn (1):

where:

$$
U_{i}=\beta_{0 i}+\sum_{k=1}^{k} \alpha_{i k}\left(X_{i k}\right)+\sum_{k=1}^{k} \beta_{i k}\left(Y_{i k}\right),
$$

$\beta_{0=}$ alternative-specific constant

$\alpha_{i}=$ weight (or parameter) associated with personal attributes $\mathrm{X}_{1}, \ldots, \mathrm{X}_{\mathrm{k}}$ of individual $\mathrm{i}$

$\beta_{i}=$ weight (or parameter) associated with street attributes $\mathrm{Y}_{1}, \ldots, \mathrm{Y}_{\mathrm{k}}$ available to an individual

$X_{i}=$ personal attributes of the individual i

$Y i=$ street characteristics available to individual $\mathrm{i}$

${ }^{1}$ (According to Dijkstra's algorithm, an agent selects the unvisited junction with the lowest distance from the destination). 
The selection of attributes/factors affecting on-street parking choice associated with personal characteristics of individuals and street attributes is explained in the section below.

\section{IDENTIFICATION OF FACTORS AFFECTING ON-STREET PARKING CHOICE}

It is necessary for urban planners to understand which factors can influence motorists' parking choice behaviour to design efficient parking policies. Such policies can help encourage people to use other modes such as public transport and cycling rather than using car. This is important for improving traffic congestion, air pollution and improving residence quality for city centres (Feeney [7]) and (Hess and Polak [8]). Therefore, policy makers are always interested to identify some factors considered by parking users. The variations of these factors can lead to changes in parking choice behaviour. Changes in parking users' behaviour towards an applied parking policy includes changing parking locations, parking time, travelling modes or abandoning the trip (Gillen [9]). Parking choice can be defined by two major choices: the parking type (on-street or off- street) and the parking location which is a representation of several sub choices of trip and parking attributes. Initially, studies described parking at a more aggregated spatial level and more specifically the attributes which shape people's preferences on choosing the desired parking destination (among alternatives). Studies such as [9]-[12] investigated factors that can significantly influence parking users' behaviours with respect to off-street parking choice. Furthermore, there are some studies, which combined parking choices with other characteristics such as trip purpose (van der Waerden et al. [13]) mode choice (Coppola [14]) and traffic flow (Carrese et al. [15]). In general, parking choice is a complex process and is influenced by many factors. These include travel time to parking places, availability of parking spaces, walking time to destination, the distance to pay machines, pricing. Also, the personal characteristics of car drivers such as gender, age and travelling group, etc. will also have impacts on parking choices (van der Waerden et al. [13]). The basic parking choice related attributes identified from the literature are presented in Table 1.

Table 1: Parking related attributes examined in literature. (Source: Chaniotakis et al. [16]).

\begin{tabular}{|l|l|}
\hline Parking cost & $\begin{array}{l}\text { Basic parameters } \\
\text { related to } \\
\text { parking }\end{array}$ \\
\cline { 1 - 1 } $\begin{array}{l}\text { Walking Time (between the parking } \\
\text { space and the final destination) }\end{array}$ & \\
\cline { 1 - 1 } Parking type & \\
\cline { 1 - 1 } Parking search time & $\begin{array}{l}\text { Basic parameters } \\
\text { of driver and trip } \\
\text { characteristics }\end{array}$ \\
\cline { 1 - 1 } Distance to destination & \\
\cline { 1 - 1 } Parking duration & \\
\cline { 1 - 1 } Gender & \\
\cline { 1 - 1 } Value of time/ Income & \\
\cline { 1 - 1 } Trip purpose & \\
\cline { 1 - 1 } Occupation & \\
\cline { 1 - 1 } Parking guidance information & \\
\cline { 1 - 1 } Allegal parking fine &
\end{tabular}


Several studies have been conducted to identify the factors affecting the parking choice behaviour of motorists regarding on-street parking. (Teknomo and Hokao [17]) investigated that factors such as availability of parking spaces, trip purpose, search time, queue time, walking time parking fee, security and comfortability effect on-street parking choice behaviour of individuals. (Waraich and Axhausen [4]) declared that pricing is the most influential determinant in parking choice behaviour. (Coppola [14]) studied the influence of factors such as illegal parking, parking duration, search time, parking cost, occupancy and trip purpose and concluded that parking cost and search time significantly influence parking choice behaviour. The details of factors identified by [18]-[21] are presented the Table 2 .

Table 2: Factors influencing on-street parking choice behaviour.

\begin{tabular}{|c|c|}
\hline Study & Factors influencing parking choice \\
\hline Tsamboulas [18] & $\begin{array}{ll}- & \text { Difference in walking distance } \\
\text { - } & \text { Initial walking time } \\
\text { - } & \text { Parking fee } \\
\text { - } & \text { Trip purpose }\end{array}$ \\
\hline Coppola, 2002 & $\begin{array}{ll}- & \text { Illegal parking } \\
- & \text { Parking duration } \\
- & \text { Search time } \\
- & \text { Parking cost } \\
- & \text { Occupancy } \\
- & \text { Trip purpose }\end{array}$ \\
\hline Borgers et al. [19] & $\begin{array}{ll}- & \text { Distance between parking and home } \\
\text { - } & \text { Visibility of the car } \\
\text { - } & \text { Motorized traffic in residential street } \\
\text { - } & \text { Security }\end{array}$ \\
\hline Kobus et al. [20] & $\begin{array}{ll}- & \text { Price of parking } \\
- & \text { Parking duration }\end{array}$ \\
\hline Brooke et al., 2014 & $\begin{array}{ll}- & \text { Search Time } \\
- & \text { Walk time } \\
- & \text { Trip purpose } \\
- & \text { Parking habit } \\
- & \text { Number of Parking Places Visited } \\
- & \text { Familiarity } \\
- & \text { Trip Time (Access Time) } \\
- & \text { Parking Duration } \\
- & \text { Heavy equipment } \\
- & \text { Parking Bay Type } \\
- & \text { Type of Carriageway } \\
- & \text { Parking Bay Type } \\
- & \text { Direction of Traffic Flow } \\
- & \text { Side(s) on which Parking Spaces are located } \\
- & \text { Carriageway Side(s) } \\
- & \text { Road Width } \\
- & \text { Direction of Traffic Flow }\end{array}$ \\
\hline Chaniotakis and Pel [16] & $\begin{array}{ll}- & \text { Parking type } \\
- & \text { Walking distance to destination } \\
- & \text { Travel time } \\
- & \text { Parking fee }\end{array}$ \\
\hline
\end{tabular}


The literature search reveals that limited research has been conducted on studying the influences of parking features other than pricing, such as walking distance and cruising time for parking spaces [10], [16]. In this paper, the parking choice decision is considered to be based on the street characteristics, therefore several parking related characteristics are investigated considering on-street parking. A list of characteristics have been identified that affect parking choice of drivers. Although parking tariff and distance to destination significantly affect parking choice as indicated by several studies e.g. [8], [10], [11], there are other factors that affect parking decisions keeping in view the parking situation. The factors (attributes) related to on-street parking choice are also affected by number of cars in the street (occupancy) and presence of security. The attributes, measurement unit for each attribute and specification of the number and magnitudes of attribute levels describing a parking situation in a street are listed in the Table 3.

The street characteristics considered in this model include parking cost, distance to destination, available security and occupancy rate as described above. The attribute levels of the above-mentioned attributes have been deduced from the literature (see section 4 ). In order to identify the significance of these street attributes on parking choice, an online questionnaire regarding on-street parking preferences was designed. The stated choice data collected, was analysed using multinomial logit model (MNL). The part-worth utilities and significance level of street attributes are listed below in Table 4.

Table 3: Factors affecting on-street parking choice behaviour.

\begin{tabular}{|c|c|c|c|}
\hline Sr. No. & Attributes & Description & Attribute level \\
\hline 1. & $\begin{array}{l}\text { Parking } \\
\text { costs per } \\
\text { hour }\end{array}$ & $\begin{array}{l}\text { The price that the driver has to } \\
\text { pay for parking its car usually } \\
\text { defined on hourly basis. }\end{array}$ & $\begin{array}{ll}\text { 1. } & 1 \text { euro/hour } \\
2 . & 2 \text { euro/hour } \\
\text { 3. } & \text { free }\end{array}$ \\
\hline 2. & $\begin{array}{l}\text { Distance to } \\
\text { destination }\end{array}$ & $\begin{array}{l}\text { The distance of the street where } \\
\text { car is parked from the } \\
\text { destination. }\end{array}$ & $\begin{array}{ll}\text { 1. } & 100 \mathrm{~m} \\
\text { 2. } & 200 \mathrm{~m} \\
\text { 3. } & 300 \mathrm{~m}\end{array}$ \\
\hline 3. & $\begin{array}{l}\text { Occupancy } \\
\text { rate }\end{array}$ & $\begin{array}{l}\text { The number of cars parked in a } \\
\text { street (expressed as percentage) }\end{array}$ & $\begin{array}{ll}\text { 1. } & \text { Low, occupancy, } 50 \% \\
\text { 2. } & \text { Medium occupancy, } 75 \% \\
\text { 3. } & \text { High occupancy, } 100 \%\end{array}$ \\
\hline 4. & $\begin{array}{l}\text { Available } \\
\text { security }\end{array}$ & $\begin{array}{l}\text { Presence of security features in } \\
\text { a street to avoid theft/vandalism } \\
\text { of vehicles. }\end{array}$ & $\begin{array}{ll}\text { 1. } & \text { Nothing } \\
\text { 2. } & \text { Guards } \\
\text { 3. } & \text { CCTV camera }\end{array}$ \\
\hline
\end{tabular}

Table 4: Estimated model parameters of street characteristics. $(\mathrm{N}=548)$.

\begin{tabular}{|l|c|c|}
\hline \multicolumn{1}{|c|}{ Street Attributes } & $\begin{array}{c}\text { Part- } \\
\text { worth } \\
\text { utilities }\end{array}$ & $\begin{array}{c}\text { Significance } \\
\text { level }\end{array}$ \\
\hline Over all utility (intercept) & 1.505 & $0.000^{*}$ \\
\hline Parking cost (1 euro/hour) & -0.867 & $0.000^{*}$ \\
\hline Distance to destination (100m) & -0.322 & $0.089 * * *$ \\
\hline Occupancy (Low occupancy, 50\%) & -0.431 & $0.010^{* *}$ \\
\hline Available security (Guards) & 0.280 & $0.042^{* *}$ \\
\hline
\end{tabular}


In the context of car drivers' parking preferences regarding on-street parking characteristics the value of parameter for parking costs has a negative sign $(-0.861)$ this shows that if the cost is less more people will prefer to park on-street. Similarly, the parameters of distance to destination $(-0.322)$ and occupancy $(-0.431)$ show that people will prefer to park on-street if distance and occupancy are less. However, on-street parking preference is affected by availability of security $(+0.280)$ but in this attribute the positive sign of the parameter indicates that a street with higher security will highly affect people's preference to park in that street.

In general, it can be concluded that part-worth utilities of parking cost, distance to destination, occupancy and security are in the expected direction, giving face validity to the estimated model. The model fitting information $(p=0.000)$ indicates that the overall model is statistically significant. According to the proposed extension in agents' parking choice behaviour, every agent in the model has its personal characteristics (e.g. age, gender, income) and trip characteristics (e.g. purpose, duration). The agent starts moving towards the destination, while passing through the streets it evaluates street characteristics such as distance to destination, parking cost, security and payment options. Based on the street conditions the agent decides to park in the street or continue driving.

\section{CONCLUSION}

The aim of this research is to propose a behavioural model of parking choice that improves the representation of parking choice process in an existing agent based parking model PARKAGENT. In this paper attention is paid to develop a discrete choice approach to determine on-street parking choice behaviour of car drivers in PARKAGENT model. Therefore, several street related factors have been investigated based on literature. It is deduced that car drivers' decision to park in a street also depends on the prevailing parking situation of street certain street related factors/characteristics. PARKAGENT is used as a parking policy evaluation tool, it is important to include street related factors when analysing the effects of suggested parking measures. These simulation models provide planners with a clear view that how the potential users will react to the new parking policies. Literature on parking choice does not provide insights regarding the influence of factors representing the parking situation such as occupancy, availability of security, etc. on car drivers' preferences. Therefore, the researchers have used a discrete choice approach to investigate significant factors affecting on-street parking choice behaviour of car drivers. It can be noticed, that parking cost, distance to destination, security level and occupancy significantly influence onstreet parking choice. Hence, it is proposed that in PARKAGENT model, agents should consider street attributes (e.g. parking cost, distance to destination and occupancy) while making on-street parking choice. This behavioural modelling approach will enhance the simulating capability of PARKAGENT model by representing the parking choice decision of agents in a more realistic way. The next step in this research is to perform simulations for model calibration to measure the predictive capability of the extended PARKAGENT model.

\section{REFERENCES}

[1] Train, K., Discrete Choice Methods with Simulation. Cambridge University Press, 2003

[2] Benenson, I., Martens, K. \& Birfir, S., Agent-based model of driver parking behaviour as a tool for urban parking policy evaluation. In Proceedings of the 10th AGILE International Conference on GIScience 2007. 
[3] Dieussaert, K., Aerts, K., Steenberghen, T., Maerivoet, S. \& Spitaels, K., SUSTAPARK: an agent-based model for simulating parking search. In AGILE International Conference on Geographic Information Science, Hannover, 2009.

[4] Waraich, R. \& Axhausen, K., Agent-based parking choice model. Transportation Research Record: Journal of the Transportation Research Board, 23(19), pp. 39-46. 2012.

[5] Ben-Akiva, M.E., Ramming, M.S. \& Bekhor, S., Route Choice Models. In: Schreckenberg M. \& Selten R. (eds) Human Behaviour and Traffic Networks. Springer, Berlin, Heidelberg, 2004.

[6] Vitetta, A., A quantum utility model for route choice in transport systems, Travel Behaviour and Society, 3, pp. 29-37. 2007.

[7] Feeney, B. P., A review of the impact of parking policy measures on travel demand. Transportation Planning and Technology, 13(4), pp. 229-244, 1989.

[8] Hess, S. \& Polak, J.W., Mixed Logit estimation of parking type choice. 83rd Annual Meeting of the Transportation Research Board, Washington, DC pp. 561-582, 2004.

[9] Gillen, D. W., Parking policy, parking location decisions and the distribution of congestion. Transportation, 7(1), pp. 69-85. 1978.

[10] Hunt, J. D. \& Teply, S., A nested logit model of parking location choice. Transportation Research Part B: Methodological, 27(4), pp. 253-265, 1993.

[11] Lambe, T. A., Driver choice of parking in the city. Socio-Economic Planning Sciences, 30(3), pp. 207-219, 1996.

[12] van der Goot, D., A model to describe the choice of parking places. Transportation Research Part A: General, 16(2), pp. 109-115, 1982. https://doi.org/10.1016/01912607(82)90003-6.

[13] van der Waerden, P., Borgers, A. \& Timmermans, H., Travelers micro-behavior at parking lots: a model of parking choice behavior. The 82nd Annual Meeting of the Transportation Research Board, pp. 1-18, 2003.

[14] Coppola, P., A joint model of mode/parking choice with elastic parking demand. Transportation Planning, Applied Optimization, Springer US 64, pp. 85-104, 2004.

[15] Carrese, S., Gori, S. \& Picano, T., Relationship between parking location and traffic flows in urban areas. Bianco, L. \& Toth, P., eds, Advanced Methods in Transportation Analysis, Transportation Analysis, Springer Berlin Heidelberg pp. 183-214, 1996.

[16] Chaniotakis, E. \& Pel, A. J., Drivers' parking location choice under uncertain parking availability and search times: A stated preference experiment. Transportation Research Part A: Policy and Practice, 82, pp. 228-239, 2015.

[17] Teknomo, K. \& Hokao, K., Parking behavior in central business district: A study case of Surabaya, Indonesia. Journal, 2(2), pp. 551-570, 1997.

[18] Tsamboulas, D. A., Parking fare thresholds: a policy tool. Transport Policy, 8(2), pp. 115-124, 2001.

[19] Borgers, A.W.J., Kemperman, A., Adam Astrid, T., Lieke, L.M.M. \& Timmermans, H.J.P., Measuring preferences for parking facilities in old residential areas. AUBC. 2010.

[20] Kobus, M., Puigarnau, E.G., Rietveld, P. \& Van Ommeren, J.N., The on-street parking premium and car drivers' choice between street and garage. Parking, Regional Science and Urban Economics 43(2), pp. 395-403, 2012.

[21] Brooke, S.L., Ison, S.G. \& Quddus, M.A., Factors influencing parking search time using multilevel modelling: A case study of East Midlands, UK.Conference proceedings presented at the Transportation Research Board (TRB), January 2015, Washington DC, USA, 2015. 